\title{
Samorefleksije studenata učiteljskog studija o praktičnoj izvedbi nastave likovne kulture
}

Marijana Županić Benić*
marijana.zbenic@ufzg.hr
UDK: $377.8-057.875(497.521 .2)$

7.01:37

Pregledni članak / Review

Primljeno: 1. prosinca 2017. Prihvaćeno: 16. veljače 2018.

Sposobnost samorefleksije smatra se jednim od važnih područja za uvodenje pozitivnih promjena u učiteljskoj praksi te profesionalnom razvoju učitelja. Razmatrati pitanje sposobnosti samorefleksije studenata o njihovoj praktičnoj izvedbi nastave likovne kulture značajan je aspekt unapređivanja kvalitete nastavnog procesa i inicijalnog obrazovanja učitelja. Radi toga na Učiteljskom fakultetu Sveučilišta u Zagrebu provedeno je kvalitativno istraživanje u kojem se samorefleksijom nastojalo istražiti što studenti misle o vlastitoj izvedbi javnoga sata iz likovne kulture. U istraživanju su sudjelovali studenti četvrte godine razredne nastave, a provedeno je anonimnim anketnim upitnikom u ljetnom semestru ak. god. 2016./2017. U ovom radu izneseni su podaci koji su dobiveni odgovorima na otvorena pitanja, a razvrstani su u šest kategorija: 1. strahovi prije izvedbe javnoga sata, 2. poteškoće za vrijeme pisanja pripreme, 3. poteškoće tijekom rada s učenicima, 4. samoprocjena uspješnosti izvedbe javnoga sata, 5. kako poboljšati izvedbu javnoga sata $i$ 6. što bi mijenjali u izvedbi javnoga sata. Rezultati su pokazali da kod studenata nedostatak vremena za realizaciju nastavnoga sata najčešce izaziva strah, a ujedno se ističe i problem integracije teorijskoga znanja u učiteljskoj praksi, primjerice, problemi u pisanju pripreme, komunikacija s učenicima $i$ korištenje likovnoga jezika u objašnjavanju likovnih problema i pojmova. Dobiveni rezultati pružaju uvid u mišljenja studenata koja su proizašla iz njihove samorefleksije o izvedbi javnoga sata iz metodike likovne kulture i važnost samorefleksije za inicijalno obrazovanje i razvoj budućih učitelja.

Ključne riječi: refleksija i samorefleksija, obrazovanje učitelja, kvaliteta studija, metodika likovne kulture.

\footnotetext{
* Dr. sc. Marijana Županić Benić, predavačica na Učiteljskom fakultetu Sveučilišta u Zagrebu; Savska c. 77, HR-10000 Zagreb.
} 


\section{Uvod}

Programi inicijalnog obrazovanja učitelja neizostavno se temelje, osim na teoriji, i na uključivanju praktičnih nastavnih vještina, metodika, kao važan dio pripreme učitelja za vođenje nastave. Unatoč tomu što studenti imaju nastavnu praksu te samostalno izvode nastavu unutar metodičkih vježbi iz različitih predmeta, između znanja koje se stječe na visokoškolskim ustanovama i znanja koja su potrebna u radu s učenicima u učionici postoji velik raskorak. Učitelj u praksi često nailazi na nepredvidive situacije u kojima je potrebno vladati različitim strategijama, improvizirati i biti inventivan. ${ }^{1}$ Situacije u kojima teorijske osnove koje studenti, budući učitelji, stječu inicijalnim obrazovanjem i njihova primjena u pedagoškoj praksi središnji je i ključan trenutak u razvoju svakog profesionalca. ${ }^{2}$

U sklopu tradicionalnih programa inicijalnog obrazovanja učitelja previše se pozornosti obraćalo poučavanju odgojno-obrazovnih metoda, a osobni razvoj učitelja i njihovih profesionalnih kompetencija nije dio većine takvih programa. ${ }^{3}$ Takvi programi ne mogu adekvatno pripremiti studente, buduće učitelje, za rad jer se bez sposobnosti samorefleksije ne mogu razviti dobre profesionalne kompetencije učitelja. ${ }^{4}$ Kao jedno od značajnih obilježja profesionalne kompetentnosti učitelja, refleksija i refleksivno razmišljanje smatraju se okosnicom obrazovanja budućih učitelja, ali i njihova daljnjeg profesionalnog razvoja i jednom od temeljnih kompetencija nužnih za kvalitetno poučavanje. ${ }^{5}$ Recentni autori smatraju da je promišljanje, refleksija nastavnog procesa kroz iskustveno učenje temelj profesionalnog obrazovanja učitelja utemeljenog na kvaliteti. ${ }^{6}$ Unatoč prihvaćenosti refleksivne prakse kao jedne od bitnih učitelj-

${ }^{1}$ Usp. Mirjana ŠAGUD, Odgajatelj kao refleksivni praktičar, Petrinja, Visoka učiteljska škola, 2006, 65 .

${ }^{2}$ Usp. isto, 60.

${ }^{3}$ Usp. Hea-Jin LEE, Understanding and assessing preservice teachers' reflective thinking, Teaching and Teacher Education, 21 (2005) 6, 699-715, 700.

${ }^{4}$ Usp. John DEWEY, How we think. A restatement of the relation of reflective thinking to the educative process, Boston, MA, Heath and Company, 1993, 36.

${ }^{5}$ Usp. Marko JURČIĆ, Kompetentnost nastavnika - pedagoške i didaktičke dimenzije, Pedagogijska istraživanja, 11 (2014) 1, 77-93; Fred KORTHAGEN, Angelo VASALOS, Levels in reflection: Core reflection as a means to enhance professional growth, Teachers and Teaching, 11 (2005) 1, 47-71; David A. KOLB, Experiential learning. Experience as the source of learning and development, New Jersey, Prentice Hall, 1984; Donald SCHÖN, Educating the reflective practitioner, San Francisco, CA, Jossey-Bass, 1987; Maura STRIANO, La razionalità riflessiva nell'agire educativo, Napoli, Liguori Editore, 2001; Vlasta VIZEK VIDOVIĆ, Vesna VLAHOVIĆ ŚTETIĆ, Modeli učenja odraslih i profesionalni razvoj, Ljetopis socijalnog rada, 14 (2007) 2, 283-310; Vlasta VIZEK VIDOVIĆ (ur.), Učitelji i njihovi mentori. Uloga mentora u profesionalnom razvoju učitelja, Zagreb, Institut za društvena istraživanja, 2011.

${ }^{6}$ Usp. Vizek Vidović, Vlahović Štetić, nav. dj.; Sanja BILAČ, Dubravka MILJKOVIĆ, Utjecaj refleksivne prakse na samoprocjenu ponašanja i zadovoljstvo poslom učitelja u upravljanju razredom i disciplinom, Školski vjesnik - časopis za pedagogijsku teoriju i praksu, 65 (2006) 3, 357-377. 
skih kompetencija, još uvijek ne postoje jedinstvene definicije ni jasne strategije primjene refleksije u osposobljavanju budućih učitelja u inicijalnom obrazovanju, stoga nailazimo na različite modele i pristupe.

John Dewey filozofski je razradio problem refleksivnog mišljenja definirajući refleksiju kao »aktivno, konstantno i pažljivo razmatranje uvjerenja ili znanja u okviru činjenica koje ih podržavaju i zaključaka kojima teže«.7 Sam proces refleksije odvija se tako da praktičar spontano interpretira svoje iskustvo, koje je predmet refleksije. Iako je John Dewey prvi isticao važnost refleksivnog mišljenja, refleksiju među učiteljima tek krajem 20. stoljeća popularizira Donald Schön tako što uvodi pojam refleksivne prakse u područje obrazovanja učitelja. ${ }^{8}$ Važno je istaknuti i teoriju Davida A. Kolba. On refleksiju opisuje kao mentalnu aktivnost unutar iskustvenog učenja koja prethodi samom učenju kroz proces promatranja te $u$ svojoj teoriji u procesu učenja ističe upravo iskustveno učenje kao preduvjet uspješne primjene teorijskih koncepata u praktičnim situacijama, ${ }^{9}$ čime se nadovezuje na teoriju filozofskoga pragmatizma Johna Deweya, razvojnu psihologiju Jeana Piageta i socijalnu psihologiju Kurta Lewina.

Takvi modeli mogu se primijeniti u inicijalnom obrazovanju učitelja tamo gdje se konkretno iskustvo odnosi na promatranje nastave ili osobnu izvedbu nastavne jedinice. ${ }^{10}$ Refleksivno promatranje uključuje kritičko promišljanje o vlastitoj ili tuđoj praktičnoj izvedbi, apstraktno razmišljanje podrazumijeva analizu, uočavanje obrazaca ponašanja, povezivanje $\mathrm{s}$ teorijom, planiranje $\mathrm{i}$ predviđanje na temelju viđenoga, a pod aktivnim eksperimentiranjem smatra se provjera izvedenih zaključaka u novoj pedagoškoj situaciji. ${ }^{11}$ Međutim, i danas je teško odrediti što točno proces refleksivnog mišljenja podrazumijeva jer se u jednom procesu samorefleksije može obuhvatiti više pristupa obrade teme (analiza/sinteza/prosudba), područja refleksije (teorija/praksa/vrijednosti), stilova (racionalnost/akcijska refleksija), vrijeme refleksije (prije/nakon aktivnosti) i predmeta refleksije (nastavni sadržaj/odgojni procesi/kurikulum). ${ }^{12}$ Samorefleksija može se i dokumentirati u više formata (prijedlog/studija slučaja/strategija) i koristiti se intuitivno ili formalno. ${ }^{13}$ Ovisno o navedenim karakteristikama, dolazi se do različitog profila procesa i ishoda samorefleksije, ali prethodna istraživanja pokazala su da svaki oblik evidentiranja refleksije, neovisno o tome

\footnotetext{
${ }^{7}$ Dewey, nav. dj., 7.

8 Usp. Schön, nav. dj., 6.

${ }^{9}$ Usp. Kolb, nav. dj., 6.

${ }^{10}$ Usp. Vlasta VIZEK VIDOVIĆ (ur.), Cjeloživotno obrazovanje učitelja i nastavnika: višestruke perspektive, Zagreb, Institut za društvena istraživanja, 2005, 221.

${ }^{11}$ Usp. isto, 294.

${ }^{12}$ Usp. Lya KREMER-HAYON, Reflection and professional knowledge. A conceptual framework, u: Christopher DAY, Maureen POPE, Pam DENICOLO (ur.), Insights into teachers' thinking and practice, London, The Flamer Press, 1990, 57-70, 68.

${ }^{13}$ Usp. isto, 68.
} 
orijentira li se isključivo na iskustva u praksi ili na kognitivne procese studenata, može pomoći budućim učiteljima u osobnom i profesionalnom razvoju. ${ }^{14}$

Na modelima koje su izradili John Dewey i Donald Schön utemeljeni su mnogi drugi modeli refleksivne prakse koji sagledavaju proces iz više perspektiva. ${ }^{15}$ Zbog različitih pristupa refleksivnoj praksi, teško je standardizirati takvu praksu u inicijalnom obrazovanju učitelja, ali upravo se ta raznolikost smatra korisnom za razmatranje jednog problema iz više perspektiva da bi se problem mogao prepoznati i riješiti u praksi ${ }^{16}$ Različiti modeli nude i različite metode refleksije, kao što su dnevnici koji omogućavaju cikličko sagledavanje problema na više razina ${ }^{17}$ ili intervjui s kolegama koji omogućavaju sagledavanja problema iz više perspektiva. ${ }^{18}$

Proces refleksije promatran je iz perspektive osobe koja uči pa u takvom modelu proces refleksije podrazumijeva iskustveno učenje promatrano s ponašanjem, idejama i osjećajima uključenog pojedinca radi poboljšanja profesionalne prakse. ${ }^{19}$ Navedeni model razlikuje tri faze refleksivnog procesa: iskustvo, refleksivne procese, ishode učenja.

Refleksivna bi praksa trebala biti integrirana u programe obrazovanja učitelja, a može se izvoditi u obliku vođenja refleksivnog dnevnika, refleksivnih intervjua, refleksivnog promatranja kolega i na grupnim seminarima kolaborativne refleksije. ${ }^{20}$ Takav pristup trebao bi biti obavezan kod metodičkih predmeta $\mathrm{u}$ inicijalnom obrazovanju. Primjerice, analizom programa inicijalnog obrazovanja učitelja razredne nastave Sveučilišta u Wisconsinu-Madisonu, Kenneth Zeichner i Daniel Liston navode da je vođenje dnevnika o iskustvima iz praktikuma jedna od obaveznih aktivnosti studenata. ${ }^{21}$ Dnevnik se vodi

\footnotetext{
${ }^{14}$ Usp. John D. BAIN, Roy BALLANTYNE, Jan PACKER, Colleen MILLS, Using journal writing to enhance student teachers' reflectivity during field experience placements, Teachers and Teaching, 5 (1999) 1, 51-73; Deborah S. YOST, Sally M. SENTNER, Anna FORLENZA-BAILEY, An examination of the construct of critical reflection. Implications for teacher education programming in the $21^{\text {st }}$ century, Journal of Teacher Education, 51 (2000) 1, 39-49.

${ }^{15}$ Usp. Anthony CLARKE, Professional development in practicum settings: Reflective practice under scrutiny, Teaching and Teacher Education, 11 (1995) 3, 243-261; Fred KORTHAGEN, Linking reflection and technical competence. The logbook as an instrument in teacher education, European Journal of Teacher Education, 22 (1999) 2-3, 191-207; Alan REIMAN, The evolution of the social roletaking and guided reflection framework in teacher education. Recent theory and quantitative synthesis of research, Teaching and Teacher Education, 15 (1999) 597-612.

${ }^{16}$ Usp. John WARD, Suzanne McCOTTER, Reflection as a visible outcome for preservice teachers, Teaching and Teacher Education, 20 (2004) 3, 243-257, 245.

${ }^{17}$ Usp. Dawn FRANCIS, The reflective journal. A window to preservice teachers' practical knowledge, Teaching and Teacher Education, 11 (1995) 3, 229-241, 231.

${ }^{18}$ Usp. Sunya COLLIER, Characteristics of reflective thought during the student teaching experience, Journal of Teacher Education, 50 (1999) 3, 173-181, 175.

${ }^{19}$ Usp. David BOUD, Rosemary KEOGH, David WALKER, Reflection. Turning experience into learning, London, Kogan Page, 1985, 19.

${ }^{20}$ Usp. Collier, nav. dj., 175.

${ }^{21}$ Usp. Kenneth ZEICHNER, Daniel LISTON, Teaching student teachers to reflect, Harvard Educational Review, 57 (1987) 1, 23-49, 33.
} 
u skladu s uputama koje studenti, budući učitelji, dobivaju od svojih mentora kako bi dokumentirali svoja mišljenja i stavove o tome što znači biti učitelj i kako se oni kroz praktičan rad razvijaju kao učitelji, ali i kako bi se kritički osvrnuli na konkretne situacije koje se javljaju u razredu. Osim što praksa samorefleksije pomaže studentima sagledati svoje misli o vlastitom djelovanju, dnevnici se smatraju »integralnim dijelom mentoriranja ${ }^{22}$ Studenti svoje dnevnike povremeno daju mentorima te primaju povratne informacije koje ih mogu potaknuti da se naknadno osvrnu na svoj individualni i profesionalni razvoj. U kontekstu kolegija Metodike likovne kulture, vođenje dnevnika u kojem studenti pišu svoja zapažanja sa sata likovne kulture na kojem su prisutni i promatraju rad svojih kolega, jedan je od zadataka koji služi za analizu odgledanog sata, kritičko promišljanje te kao poticaj za raspravu s kolegama i nastavnikom. Upravo u takvom refleksivnom promatranju praktične aktivnosti studenti osvještavaju strukturu nastavnog procesa te povezuju teorijsko znanje s praktičnim iskustvom.

Samorefleksija je ključan dio osposobljavanja učitelja jer iskustvo koje studenti steknu praktičnim radom s učenicima samo po sebi nije dostatno za njihov profesionalni razvoj. Praksom bez refleksije postižu se samo konvergentni ishodi poučavanja, a proces samorefleksije uvjet je za divergentno učenje, odnosno oblik učenja u kojem studenti postaju svjesni i drugih situacija ili mogućnosti poučavanja s kojima se još nisu susreli u praksi. ${ }^{23}$ Učitelji koji u svojoj odgojno-obrazovnoj praksi primjenjuju refleksiju, osim što znaju što raditi $u$ učionici, razumiju i zašto su odabrali primjenu nekog sadržaja ili metode $u$ nastavi. ${ }^{24}$ Refleksija na vlastitu izvedbu isto je tako ključan proces koji vodi do identificiranja problema u praksi da bi ih učitelji mogli pravovremeno ispraviti, a samorefleksijom mogu se ispraviti problemi vezani i uz ponašanje učitelja i uz njihova uvjerenja ili stavove koji utječu na profesionalnu praksu. ${ }^{25}$ Međutim, potrebno je napomenuti da studenti mogu efektivno koristiti refleksiju samo onda kada su upoznati s konceptom i praksom refleksije te im je potrebna i individualna orijentacija putem vodstva nastavnika i mentora kroz proces refleksije. $^{26}$

\footnotetext{
${ }^{22}$ Isto, 33.

${ }^{23}$ Usp. John LOUGHRAN, Effective reflective practice: In search of meaning in learning about teaching, Journal of Teacher Education, 53 (2002) 1, 33-43, 37.

${ }^{24}$ Usp. Lily ORLAND-BARAK, Hayuta YINON, When theory meets practice: What student teachers learn from guided reflection on their own classroom discourse, Teaching and Teacher Education, 23 (2007) 6, 957-969, 963.

${ }^{25}$ Usp. Harm TILLEMA, Belief change towards self-directed learning in student teachers: Immersion in practice or reflection on action, Teaching and Teacher Education, 16 (2000) 5, 575-591, 587.

${ }^{26}$ Usp. Collier, nav. dj., 179; Guolin LAI, Brendan CALANDRA, Using online scaffolds to enhance preservice teachers' reflective journal writing. A qualitative analysis, International Journal of Technology in Teaching and Learning, 3 (2007) 3, 66-81; Zeichner, Liston, nav. dj., 33.
} 
Poticanje studenata na refleksiju i samorefleksiju podiže kvalitetu inicijalnog obrazovanja učitelja jer im pomaže da tako bolje upoznaju praksu, ali i da kritički razmatraju svoj rad, osvijeste pogreške, čime se otvara mogućnost rasta i razvoja profesionalnih kompetencija. Student bi radi individualnog i profesionalnog razvoja trebao kontinuirano učiti eksploracijom, konstrukcijom, kooperacijom i u komunikaciji s drugima. ${ }^{27}$ Takav pristup učenju moguć je samo onda kada studenti osvijeste važnost refleksije te počnu koristiti spoznaje koje proizlaze iz takve prakse za svoje daljnje usavršavanje kao i za unapređenje suradnje i komunikacije s kolegama, roditeljima i učenicima.

\section{Metodologija - uzorak ispitanika i instrument mjerenja}

U ovom kvalitativnom ${ }^{28}$ istraživanju, u kojem se samorefleksijom nastojalo istražiti što studenti misle o vlastitoj izvedbi javnoga sata iz likovne kulture, sudjelovala su 52 ispitanika, studentice četvrte godine (nije bilo ispitanika muškog spola) razredne nastave na Učiteljskom fakultetu Sveučilišta u Zagrebu, Središnjica u Zagrebu, u dobi od 21 i 22 godine. Istraživanje je provedeno u ljetnom semestru ak. god. 2016./17., što znači da je to treći i završni semestar slušanja nastavnog predmeta Metodika likovne kulture te su studenti bili upoznati sa sadržajem predmeta i imali iskustvo vođenja nastavnog sata likovne kulture u prethodnom semestru.

Upitnik je imao šest pitanja otvorenog tipa i konstruiran je za potrebe ovog istraživanja. Ispitanici su ispunili upitnik neposredno nakon izvedbe javnog sata i nakon što su saslušali refleksije svojih kolega i nastavnika o izvedbi javnog sata. Njihovi odgovori analizirani su da bi se utvrdile i grupirale teme za svako pitanje. Upitnikom se nisu prikupljali demografski podaci ispitanika.

\section{Rezultati i rasprava}

\subsection{Strahovi prije izvedbe javnog sata}

Strahovi prije izvedbe javnog sata iz odgovora studenata na prvo pitanje »Čega sam se bojao/la prije izvedbe javnog sata iz MLK?« prikazani su u tablici 1.

\footnotetext{
${ }^{27}$ Usp. Šagud, nav. dj., 45.

${ }^{28}$ Usp. John W. CRESWELL, Qualitative inquiry \& research design. Choosing among five approaches, Thousand Oaks, CA, Sage, 2007, 60.
} 
Tablica 1. Strahovi studenata prije javnog sata $(\mathrm{N}=97)$.

\begin{tabular}{|l|c|l|}
\hline \multicolumn{1}{|c|}{ Strah } & N & \multicolumn{1}{c|}{ Opis } \\
\hline Nedostatak vremena & 28 & $\begin{array}{l}\text { Studenti se boje da će im predugo trajati motivacija, izrada } \\
\text { učeničkih likovnih radova ili cijeli sat općenito. }\end{array}$ \\
\hline Loša izvedba & 22 & $\begin{array}{l}\text { Studenti se boje da im izvedba motivacije, cijelog sata ili } \\
\text { demonstracije neće biti dobra zbog vlastitog zaborava, loše } \\
\text { pripreme, nejasnoće u izlaganju ili zbog nekih drugih razloga. }\end{array}$ \\
\hline Učenici neće razumjeti & 20 & $\begin{array}{l}\text { Strahuju da učenici neće razumjeti zadatak, ključne pojmove, } \\
\text { likovni problem ili neke druge sadržaje sata. }\end{array}$ \\
\hline Sadržaj & 8 & $\begin{array}{l}\text { Sadržaj bi mogao biti pretežak ili neadekvatan za primjenu u } \\
\text { učionici. }\end{array}$ \\
\hline Atmosfera & 8 & $\begin{array}{l}\text { Studenti se boje da bi mogli imati poteškoća s } \\
\text { uspostavljanjem discipline i da učenici neće sudjelovati u } \\
\text { nastavi. }\end{array}$ \\
\hline Pribor/materijal & 4 & $\begin{array}{l}\text { Učenici neće imati pribor/materijale ili studenti neće } \\
\text { pripremiti materijale za sat. }\end{array}$ \\
\hline Likovni rad & 4 & Likovni problemi neće biti vidljivi u finalnom produktu. \\
\hline Ništa & 3 & - \\
\hline
\end{tabular}

Studente prije javnog sata najviše je strah da neće imati dovoljno vremena za izvedbu cijelog sata $(n=13)$, motivacije $(n=9)$ ili da učenici neće imati vremena za izradu likovnih radova $(n=6)$. Loša izvedba česta je tema u odgovorima studenata, koji se boje da će loše odraditi motivaciju $(n=11)$, cijeli sat $(n=8)$ ili demonstraciju $(n=3)$. Strah od loše izvedbe $u$ odgovorima studenti uglavnom povezuju s mogućnošću da zaborave nešto važno, predstave sadržaj lošim slijedom, loše objasne likovne pojmove ili se općenito boje metodičkih i organizacijskih grešaka.

Glede ishoda predavanja, najviše se boje da učenici neće razumjeti ključne pojmove $(n=5)$, likovni problem $(n=4)$, likovnu tehniku $(n=1)$, motiv $(n=1)$ ili da neće shvatiti upute zadatka $(n=9)$, odnosno ono što studenti od njih traže. Ispitani studenti nisu uvijek obrazlagali svoje strahove vezane uz shvaćanje likovnog problema ili ključnih pojmova, ali njih devet je napomenulo da ih takvi ishodi zabrinjavaju jer su ih povezali s vlastitom lošom izvedbom motivacije ili cijelog nastavnog sata.

Od ostalih strahova ističe se pretpostavka da će sadržaj biti pretežak ili neadekvatan za nastavni sat $(\mathrm{n}=8)$, da će biti problema s priborom ili materijalima $(\mathrm{n}=4)$ te da u likovnom radu učenika neće biti vidljiv likovni problem ili da će prikaz motiva biti loš $(n=4)$. Samo tri osobe nisu izrazile strah od izvedbe javnog sata.

Navedene se odgovori mogu smatrati očekivanima jer pokazuju strahove studenata koji prije svega proizlaze iz njihove nesigurnosti od javne izvedbe zato što su početnici i nemaju iskustvo rada u učionici. To možemo povezati s teorijom u kojoj se kao ključno pitanje i problem u obrazovanju studenata budućih učitelja ističe upravo razvijanje sposobnosti integriranja teorijskih znanja 
i njihove praktične primjene u učiteljskoj praksi. ${ }^{29}$ Studenti se izvedbom javnog sata susreću s različitim zadacima koji su im na samom početku apstraktni i ne znaju koja su očekivanja nastavnika i mentora. Međutim, iskustvom sudjelovanja ili gledanja javnih izvedbi sata likovne kulture, vođenjem zabilješki dnevnika prakse i analizom sata s nastavnikom, kod studenata se postupno počinje razvijati kritičko i kreativno mišljenje koje im pomaže da objektivno sagledaju vlastitu i tuđu izvedbu javnog sata putem procesa refleksije i samorefleksije.

\subsection{Poteškoće za vrijeme pisanja pripreme}

Poteškoće u pisanju pripreme prema odgovorima studenata na drugo pitanje »Poteškoće pri pisanju pripreme?« prikazane su u tablici 2.

Tablica 2. Poteškoća s kojima se studenti suočavaju kod pisanja pripreme za javni sat $(\mathrm{N}=66)$.

\begin{tabular}{|l|c|l|}
\hline \multicolumn{1}{|c|}{ Poteškoće } & N & \multicolumn{1}{c|}{ Opis } \\
\hline Ništa & 23 & - \\
\hline Pisanje motivacije & 20 & $\begin{array}{l}\text { Općenito je studentima bilo teško pisati motivaciju, a } \\
\text { specifično imaju problema s opisima ključnih pojmova, } \\
\text { objašnjavanjem motiva te opisima likovnih problema. }\end{array}$ \\
\hline Odabir & 14 & $\begin{array}{l}\text { Odabir motiva, pitanja ili nastavnih metoda jedna je od } \\
\text { mogućih poteškoća pri pisanju pripreme. }\end{array}$ \\
\hline Ostalo & 9 & $\begin{array}{l}\text { Uglavnom određivanje korelacija s drugim predmetima, ali i } \\
\text { sve one poteškoće koje se ne mogu grupirati s drugima. }\end{array}$ \\
\hline
\end{tabular}

Studenti najčešće izjavljuju da nisu imali nikakvih poteškoća u pisanju pripreme, što je jedna osoba obrazložila kao rezultat iskustva iz prethodnog semestra: u ljetnom semestru već je svima bilo jasno na koji način strukturirati pripremu te smo iz prethodnih iskustava mogli osvijestiti koliko će nam vremena biti potrebno za objašnjavanje pojedinog pojma ili za aktivnost koju smo predvidjeli.

Motivacija je ipak i dalje najzahtjevniji dio pripreme jer je 20 studenata navelo da su imali najviše poteškoća s pisanjem motivacije. Uglavnom nisu obrazlagali svoje odgovore, ali jedna je osoba navela da je teško pisati motivaciju za razred koji ne poznaje, a pet osoba navelo je da im je pisanje objašnjenja ključnih pojmova najzahtjevniji dio pripreme. Uz općenite probleme u pisanju motivacije, najviše poteškoća studenti imaju s odabirom motiva $(n=8)$, formulacijom otvorenih pitanja $(n=5)$ i nastavnih metoda u jednom slučaju.

Od drugih poteškoća ističe se samo određivanje korelacija $(n=3)$. Ostale poteškoće navode samo pojedinačni studenti koji su imali problema s opisom demonstracije, određivanjem slijeda dijelova nastave, konkretizacijom zadata-

${ }^{29}$ Usp. Šagud, nav. dj., 61. 
ka, usklađivanjem nastavne jedinice s programom, opisivanjem aktivnosti te pisanje nastavne cjeline i teme.

Kod navedenih odgovora značajan je podatak da studenti koji već prođu jedan semestar metodičkih vježbi iz Metodike likovne kulture, ali i kroz iskustvo pisanja pripreme za druge metodičke predmete, stječu neko iskustvo i priprema im nije nepoznanica, što možemo povezati i s činjenicom da veći dio studenata neodgovaranjem na navedeno pitanje smatra da nisu imali neke poteškoće $s$ pisanjem pripreme, odnosno da im je prethodno iskustvo pomoglo u rješavanju navedenog problema. Odgovore ispitanika može se povezati s teorijom Davida Bouda i suradnika, koji ističu da je za profesionalni napredak osobe koja uči ključna refleksija putem iskustvenog učenja promatrano s ponašanjem, idejama i osjećajima uključenog pojedinca. ${ }^{30}$

\subsection{Poteškoće tijekom rada s učenicima}

Poteškoće u radu s učenicima iz odgovora studenata na treće pitanje »Poteškoće tijekom rada s učenicima?» prikazane su u tablici 3.

Tablica 3. Poteškoće s kojima se studenti suočavaju za vrijeme javnog sata $(\mathrm{N}=58)$.

\begin{tabular}{|l|c|l|}
\hline \multicolumn{1}{|c|}{ Poteškoće } & N & \multicolumn{1}{c|}{ Opis } \\
\hline Ništa & 23 & - \\
\hline Upute & & $\begin{array}{l}\text { Krivi smjer realizacije učenika koji nisu razumjeli upute } \\
\text { izrade likovnih radova, s time da je u nekim situacijama riječ } \\
\text { o učenicima s posebnim potrebama. }\end{array}$ \\
\hline Izvedba & 5 & $\begin{array}{l}\text { Studenti imaju poteškoća u održavanju discipline i razrednih } \\
\text { pravila. }\end{array}$ \\
\hline Materijali/tehnike & 3 & Poteškoće koje su učenici imali s materijalima i tehnikama. \\
\hline Okolnosti & 3 & Učitelj ili učiteljica miješaju se u rad ili nedostaje vremena. \\
\hline
\end{tabular}

Tijekom rada s učenicima većina studenata, njih 31, izjavljuje da nisu imali nikakve značajne probleme. Većina problema nastaje kod davanja uputa pa su po tom pitanju studenti dali 16 komentara. U devet slučajeva učenici su krenuli krivim smjerom u realizaciji jer nisu shvatili upute pa je bilo potrebno dodatno ih usmjeravati tijekom realizacije. Jedna osoba priznaje da učenici nisu bili na vrijeme upozoreni pa su krenuli krivim smjerom, pritom realizacija nije bila u potpunosti prema planu.

U tri slučaja studenti su imali nešto manjih poteškoća u radu s učenicima $\mathrm{s}$ posebnim potrebama, ali u sva tri slučaja učenici su, uz samo manje teškoće, uspješno sudjelovali u nastavi. Ipak, jedna studentica izrazila je i želju da stekne više znanja i iskustva koje je potrebno za rad s takvom djecom: »Voljela bih da negdje mogu naučiti više o takvoj djeci i bolje naučiti kako raditi s njima.»

\footnotetext{
${ }^{30}$ Usp. Boud, Keogh, Walker, nav. dj., 19.
} 
Ostale vrste poteškoća vezane uz okolnosti $(\mathrm{n}=3)$ i izvedbu nastave $(\mathrm{n}=5)$ uglavnom nisu bile učestale, ali vrijedno je istaknuti da su dvije osobe imale poteškoća zbog miješanja učitelja i učiteljice u nastavu.

Studentima javna izvedba nastavnog sata čini jednu od najstresnijih situacija tijekom studija prvenstveno zato što ne poznaju učenike s kojima će raditi, a ujedno ni njihove individualne potrebe, što možemo uočiti u navedenim komentarima.

\subsection{Samoprocjena uspješnosti izvedbe javnog sata}

Samoprocjene uspješnosti izvedbe javnog sata iz odgovora studenata na četvrto pitanje U $\mathrm{U}$ čemu sam bila uspješna?« prikazane su u tablici 4.

Tablica 4. Samoprocjena uspjeha studenata na javnom satu $(\mathrm{N}=114)$.

\begin{tabular}{|l|c|l|}
\hline Samoprocjena uspjeha & $\mathbf{N}$ & \multicolumn{1}{c|}{ Opis } \\
\hline Izvedba dijelova sata & 36 & $\begin{array}{l}\text { Studenti su zadovoljni svojom izvedbom cijelog nastavnog } \\
\text { sata ili nekim dijelom nastavnog sata. }\end{array}$ \\
\hline Atmosfera & 30 & Ostvareno je radno, disciplinirano i motivirano okruženje. \\
\hline Objašnjavanje & 21 & $\begin{array}{l}\text { Studenti su zadovoljni kako su objasnili pojmove, likovne } \\
\text { probleme, zadatke, tehnike, motive ili teme učenicima. }\end{array}$ \\
\hline Ishodi & 11 & Učenici shvaćaju ili usvajaju ono što studenti poučavaju. \\
\hline Vođenje sata & 9 & Primjena nastavnih metoda i dobra organizacija. \\
\hline Priprema & 7 & Smatraju da im je sat bio uspješan zbog dobre pripreme. \\
\hline
\end{tabular}

Studenti su najčešće navodili dijelove sata za koje su smatrali da su bili dobro odrađeni. Od 36 komentara o dobroj odradi sata, njih 23 navodi da je motivacija bila dobro odrađena i da su učenici bili motivirani za rad. Studenti su isto tako bili zadovoljni i atmosferom koju su ostvarili u razredu, što se vidi po njihovim komentarima koji navode dobru komunikaciju u 15 slučajeva, aktivnu suradnju učenika u sedam slučajeva, dobru radnu i discipliniranu atmosferu u šest slučajeva te dobar odnos s učenicima u dva slučaja.

Prema 21 komentaru, studenti su smatrali da su dobro objasnili i pojmove, likovni problem, zadatak, likovnu tehniku, motiv i temu. Sedam komentara fokusira se na iste teme, ali govore o uspjesima kao o ishodu javnog sata pa su prema njima učenici usvojili ključne pojmove, problem, tehniku te su shvatili i ostvarili zadatak. U 11 slučajeva studenti su bili zadovoljni ishodom predavanja, a uglavnom je bilo riječ o tome da su učenici shvatili i ostvarili zadatak (n = 4) ili usvojili sadržaj $(\mathrm{n}=3)$.

Najmanji broj komentara na vlastite uspjehe odnosi se na vođenje sata ( $\mathrm{n}=$ 9) i pripremu $(n=7)$. Glede vođenja sata, studenti su bili zadovoljni činjenicom da su individualno radili s učenicima, uspješno integrirali likovnu kulturu s drugim predmetima, dobro organizirali dijelove sata, postupno objašnjavali 
sadržaj, uspješno prikrivali tremu i da su bili snalažljivi. Oni studenti koji su smatrali da su bili uspješni zbog dobro odrađene pripreme, bili su zadovoljni odabirom motiva, pripremom općenito, odabirom tehnika, nabavom i izradom specifičnih materijala i izradom plana ploče za analizu.

Visok postotak odgovora i komentara na navedeno pitanje kod studenata značajan je pokazatelj osjećaja uspješnosti prilikom izvedbe javnog sata. Odnosno, u ovom kontekstu takvi odgovori ukazuju na visok osjećaj samoefikasnosti vlastitih sposobnosti, vještina i znanja, odnosno kompetencija. Frank Pajares, u rezultatima svog istraživanja, potvrđuje da vjerovanja o samoefikasnosti ili drugih vjerovanja o sebi djeluju na izvedbu koja slijedi i to tako da utječu na napor, upornost i ustrajnost. ${ }^{31}$ Drugi pak ističu da uvjerenja o vlastitoj efikasnosti u poučavanju utječu na oblikovanje učiteljevih kompetencija u odgojno-obrazovnoj praksi. ${ }^{32}$ Stoga je važno usmjeriti studente da procesom samorefleksije znaju percipirati i dijelove svoje izvedbe u kojoj su bili uspješni i čime su zadovoljni.

\subsection{Kako poboljšati izvedbu sata likovne kulture}

Potkategorije $u$ analizi odgovora studenata na peto pitanje $» \mathrm{Na}$ čemu trebam raditi da bih poboljšao/la rad s učenicima?« prikazane su u tablici 5 .

Tablica 5. Potkategorije onoga što studenti smatraju da bi trebali popraviti $(\mathrm{N}=67)$.

\begin{tabular}{|l|c|l|}
\hline \multicolumn{1}{|c|}{ Potkategorija } & N & \multicolumn{1}{c|}{ Opis } \\
\hline Izvedba sata & 32 & Nastup studenata i kvaliteta vođenja sata. \\
\hline Rad na sebi & 17 & $\begin{array}{l}\text { Sve ono što studenti misle da bi trebali obratiti pažnju, a da } \\
\text { nije isključivo vezano uz likovnu kulturu ili poučavanje. }\end{array}$ \\
\hline Odnos s učenicima & 8 & $\begin{array}{l}\text { Sve što ima veze sa odnosom učitelja i učenika, a ponajviše } \\
\text { autoritet i suradnja. }\end{array}$ \\
\hline Ništa & 2 & \multicolumn{1}{|c|}{} \\
\hline
\end{tabular}

Većina studenata smatra da bi još trebali poraditi na svojoj izvedbi sata, a najviše ih muči vremenska organizacija $(n=11)$ cijelog sata i motivacije, $s$ time da neki žele poraditi na pravovremenim reakcijama za vrijeme rada da bi učenici radili na zadatku. Studenti isto tako smatraju da bi trebali poraditi na svom javnom nastupu govorništva $(n=8)$, jasnijoj komunikaciji s učenicima $(n=5)$ i povećati svoju snalažljivost kod nepredviđenih situacija $(n=3)$. Od rijetkih komentara vrijedi spomenuti da bi se neki studenti željeli manje fokusirati na

\footnotetext{
${ }^{31}$ Usp. Frank PAJARES, Self-efficacy beliefs in academic settings, Review of Educational Research, 66 (1996) 4, 543-578, 570.

${ }^{32}$ Usp. Donna PENDERGAST, Susanne GARVIS, Jayne KEOGH, Pre-service student-teacher self-efficacy beliefs. An insight into the making of teachers, Australian Journal of Teacher Education, 36 (2011) 12, 46-58, 47.
} 
PowerPoint kod prezentacije, bolje objasniti motiv, bolje voditi analizu radova i više se držati sadržaja bez nepotrebnih digresija.

Od općenitih komentara vezanih uz rad na sebi, studenti najčešće smatraju da trebaju poraditi na opuštenosti $(n=9)$ da bi smanjili tremu i stres. Ostali komentari studenata navode da žele poraditi na praktičnom znanju općenito (n $=3)$, unaprijediti svoje teorijsko i praktično znanje likovne umjetnosti $(\mathrm{n}=3)$, na vlastitoj kreativnosti i na svojim socijalnim vještinama.

Komentari studenata koji misle da trebaju poraditi na svojoj pripremi za nastavu $(\mathrm{n}=8)$ uglavnom su jedinstveni. Osim što dvije osobe misle da bi trebale bolje formulirati otvorena pitanja, ostali komentari javljaju se samo jednom i odnose se na bolju pripremu općenito, bolju pripremu demonstracije, prilagodbu motivacije razredu, upoznavanje i korištenje različitih nastavnih metoda, predviđanje mogućih odgovora i reakcija učenika te odabir jednostavnijih motiva.

Glede odnosa s učenicima, najveći broj studenata smatra da moraju poraditi na svojim sposobnostima održavanja discipline u razredu $(n=5)$. Od pojedinačnih komentara studenti navode da bi trebali naučiti bolje nadzirati rad učenika, odmaknuti ih od šablona i više ih uključiti u nastavu. Jedna osoba ne zna na čemu bi trebala poraditi, a jedna osoba smatra da je spremna za profesionalnu karijeru učitelja: »Smatram da sam dovoljno spreman i kompetentan za rad.»

Navedeni komentari koji proizlaze iz neposrednog iskustva rada studenta s učenicima, značajan su dio procesa samorefleksije jer se direktno osvještavaju i iznose kompetencije koje bi se trebale više razviti radi poboljšanja kvalitete nastave. ${ }^{33}$ Neki primjeri takvih kompetencija su: vremenska organizacija nastavnog sata, komunikacija s učenicima, nastup, govorništvo, korištenje tehničkih sredstava, uspostava discipline te snalažljivost u nepredviđenim situacijama.

\section{6. Što bi mijenjali?}

Potkategorije iz analize odgovora studenata na šesto pitanje: »Da imam priliku ponoviti isti sat, kako bi izgledao?« prikazane su u tablici 6.

Tablica 6. Potkategorije onoga što bi studenti promijenili na javnom satu $(\mathrm{N}=66)$.

\begin{tabular}{|l|c|l|}
\hline \multicolumn{1}{|c|}{ Potkategorija } & $\mathbf{N}$ & \multicolumn{1}{c|}{ Opis } \\
\hline Izvedba sata & 27 & $\begin{array}{l}\text { Sve što ima veze s nastupom i ponašanjem studenata za } \\
\text { vrijeme sata. }\end{array}$ \\
\hline Vremenska organizacija & 14 & $\begin{array}{l}\text { Komentari vezani uz planiranje i provedbu sata u skladu s } \\
\text { vremenskim ograničenjima. }\end{array}$ \\
\hline Priprema & 13 & Sve što bi studenti izmijenili kod pripreme za sat. \\
\hline Ništa & 12 & \multicolumn{2}{|l}{} \\
\hline
\end{tabular}

${ }^{33}$ Usp. Bilač, Miljković, nav. dj., 371. 
Najviše izmjena javnog sata vezano je uz izvedbu sata, a komentari su najviše vezani uz rad učenika $(n=6)$ jer studenti smatraju da bi mogli poboljšati rad učenika tako da pružaju više poticaja učenicima ili da ih više uključe $u$ nastavu putem interaktivnih aktivnosti. Kada bi im se pružila prilika, studenti bi uglavnom mijenjali slijed predavanja $(n=4)$, izvedbu analize $(n=4)$, izvedbu motivacije $(\mathrm{n}=4)$ i izvedbu demonstracije $(\mathrm{n}=3)$.

Vremenska organizacija je ono što bi studenti često mijenjali. Najčešće smatraju da bi trebalo skratiti ili produljiti motivaciju $(n=5)$, a često se javlja i želja da imaju blok sat likovne kulture $(\mathrm{n}=3)$. Po pitanju pripreme, većina studenta odabrala i drugi motiv ili osmislila bolju poziciju $(n=7)$. Druge rjeđe navedene izmjene su: pojednostavljenje zadatka, nabava materijala za učenike, manje fokusa na obrazlaganju pojmova i odabir drugačije tehnike.

Nedostatak vremena za kvalitetnu realizaciju nastavnog sata likovne kulture općenito je problem ne samo studentima već i iskusnim učiteljima, jer jedan nastavni sat u većini slučajeva nije dovoljan da bi učenici dovršili svoj likovni rad. Zapravo, ako oduzmemo ostale dijelove sata, poput demonstracije, motivacije i analize likovnog djela, učenicima ostaje 20-25 minuta za realizaciju svog likovnog rada.

Učitelji u razrednoj nastavi nedostatak vremena za kvalitetnu realizaciju likovnog rada nadoknađuju korelacijom i integracijom s drugim nastavnim predmetima ili oduzimanjem dijela sata koji slijedi nakon likovne kulture da bi učenici završili svoje likovne uratke. ${ }^{34}$ Studenti trebaju svoj sat realizirati unutar jednog školskog sata i pritom im je upravo vremenska organizacija nastavnog sata jedan od najvećih problema.

\section{Zaključak}

U ovome istraživanju cilj je bio potaknuti studente razredne nastave da razmisle o svojoj izvedbi javnog sata iz likovne kulture te se samorefleksijom nastojalo istražiti kod studenata da izraze svoje mišljenje i osvijeste s kojim su se poteškoćama susreli u pripremanju i radu s učenicima da bi ubuduće mogli poboljšati izvedbu sata. Rezultati istraživanja pokazali su u kojim se to dijelovima izvedbe javnog sata iz likovne kulture studenti osjećaju nesigurnima, čega se boje, s kojim su se poteškoćama susreli u pisanju pripreme, izvedbi i radu s učenicima, čime su zadovoljni, a što bi trebalo po njihovu mišljenju poboljšati.

\footnotetext{
${ }^{34}$ Usp. Marijana ŽUPANIĆ BENIĆ, Stručne kompetencije učitelja u kurikulu umjetničkih područja, doktorski rad, Zagreb, Filozofski fakultet Sveučilišta u Zagrebu, 2017, 243; Marijana ŽUPANIĆ BENIĆ, Opinion of Croatian teacher education students regarding the quality of the visual arts teaching didactics course, Journal of Elementary Education/Revija za elementarno izobraževanje, 10 (2017) 2-3, 324-326, 323.
} 
Iako, prema programu studija, kroz teoriju studenti dobivaju sve informacije kako uspješno izvesti nastavni sat, odnosno upoznati su i s likovnim jezikom, teorijom umjetnosti, različitim likovnim tehnikama i samom metodikom - bez neposrednog iskustva u praksi stečena teoretska znanja nisu dovoljna za kvalitetnu praktičnu izvedbu sata. Najviše strahova studenata vezano je uz nedostatak vremena da $u$ jednom satu ostvare s učenicima sve što su planirali. Isto tako, problem im je vremenska organizacija pojedinih etapa sata te smatraju da na organizaciji i komunikaciji s učenicima moraju raditi, primjerice postavljanjem otvorenih pitanja. Motivacija, kao ključan dio sata likovne kulture kojim se potiče stvaralaštvo kod učenika, također je ispitanicima problem. Važno je napomenuti da na pitanje koje se tiče zadovoljstva studenata vlastitom javnom izvedbom nailazimo na visok postotak odgovora u kojima su zadovoljni svojom izvedbom, što ukazuje na to da imaju osjećaj postignuća i učinkovitosti u nastavi.

Značenje rezultata ovog istraživanja jest to što nam uvid u samorefleksije studenata omogućava da sagledamo perspektivu studenata u njihovim prvim pokušajima neposrednog rada s djecom radi toga da ih se ohrabri i da im se pomogne u budućim nastojanjima i profesionalnom razvoju. Tek kada studenti osvijeste svoje kvalitete i nedostatke u praksi, osvještavaju i potrebu za kontinuiranim profesionalnim razvojem. $U$ ovome istraživanju oni su demonstrirali da refleksijom o pozitivnim i negativnim stranama javnog sata koji su održali mogu sebi odrediti smjernice za daljnji rad na temelju onoga što bi htjeli promijeniti u svojoj izvedbi. 


\section{Marijana Županić Benić* \\ Teacher education students' self-reflection on their performance during the visual arts teaching experience}

\section{Summary}

Self-reflection is one of the most important practices both in teaching and in the professional development of teachers. Examining the students' ability to self-reflect on their teaching practice is a significant aspect of improving the quality of their teaching, as well as the quality of their initial education. To this end, a qualitative phenomenological study was conducted at the Faculty of Teacher Education, University of Zagreb, during the second semester of the academic year 2016/17. The study attempted to examine the students' reflections on their teaching experiences in a Visual Arts class. The sample consisted of Primary Education students in their fourth year of study. The participants filled in an anonymous questionnaire with open-ended questions. This paper presents the data received during the analysis of the participants' answers, grouped in six categories: fears experienced before the lesson, difficulties associated with writing the lesson plan, difficulties experienced while working with the pupils, self-assessment of the efficacy of their teaching performance, potential areas for performance improvement, and parts of the performance the students wanted to change. The most common fear was that there would not be enough time to cover all content and activities. The participants also reported encountering difficulties with integrating theoretical knowledge with teaching practice, e.g. during planning and preparation for the lesson, communicating with the pupils, and using art-specific language in teaching visual arts problems and terms. The obtained data provides insight into the outcomes of students' self-reflections on their visual arts teaching experiences and the importance of self-reflection for the initial education and professional development of future teachers.

Key words: higher education quality, reflection, self-reflection, teacher education, visual arts teaching methodology.

(na engl. prev. Goran Brkić)

\footnotetext{
* Marijana Županić Benić, PhD, lecturer at Faculty of Teacher Education, University of Zagreb; Address: Savska c. 77, HR-Zagreb, Croatia; E-mail: marijana.zbenic@ufzg.hr.
} 